UDC 576.5.57.085.23:577.29:615.012.1

\title{
STUDY OF ANTINEOPLASTIC ACTION OF NOVEL ISOMERIC DERIVATIVES OF 4-THIAZOLIDINONE
}

\author{
V. V. CHUMAK ${ }^{1,2}$, M. R. FIL', R. R. PANCHUK ${ }^{2}$, B. S. ZIMENKOVSKY', \\ D. Ya. HAVRYLYUK ${ }^{3}$, R. B. LESYK ${ }^{3}$, R. S. STOIKA $A^{1,2}$ \\ ${ }^{1}$ Ivan Franko Lviv National Univesity, Ukraine; \\ ${ }^{2}$ Institute of Cell Biology, National Academy of Sciences of Ukraine, Lviv; \\ ${ }^{3}$ Danylo Halytsky Lviv National Medical University, Ukraine; \\ e-mail:virachumak@gmail.com
}

\begin{abstract}
Pyrazole- and aryl-substituted derivatives of 4-thiazolidinone belong to a perspective group of compounds with potential antitumor action. Earlier, we have demonstrated high toxicity in vitro of several 4-thiazolidinones derivatives towards tumor cell lines. To further enhance the antitumor activity of novel 4-thiazolidinones, their chemical scaffold was optimized, and new pyrazole-thiazolidinones were synthesized. That allowed us to combine in one molecule the potential pharmacophore centres of previously tested compounds. As a result, "hybrid" 4-thiazolidinones exhibit higher toxicity in vitro toward tumor cells of various origin. The molecular mechanisms of antineoplastic activity of these compounds and intensity of induction of apoptosis strongly depended on the position of the substituent in the thiazolidinone cycle. In particular, Les-3661 compound, containing pyrazoline fragment in the $4^{\text {th }}$ position of thiazolidinone core, exhibits 14 times higher cytotoxic activity towards tumor cells $\left(L C_{50}=3 \mu \mathrm{M}\right)$ in comparison to its 2-substituted isomer Les-3713 $\left(L C_{50}=42 \mu M\right)$. It is demonstrated that in terms of underlying molecular mechanisms for cytotoxic effect the Les-3661 compound induced caspase- 8 and caspase-9 dependent mixed-type of apoptosis, while Les-3713 induced apoptosis mediated only by the caspase- 8 .
\end{abstract}

Key words: 4-thiazolidinones, mechanisms of anticancer action, tumor cell lines.

$\mathrm{D}$ espite the influx of data in the latter decades and experience in medical science concerning oncotherapy, the search for novel chemical agents remains a high priority task, potentiated by high rate at which tumor cells attain drug resistance. Furthermore, the application of most of the existing antitumor pharmaceuticals is accompanied by the negative side effects due high unspecific toxicity.

The chemistry of 4-thiazolidinones and their related compounds, which has been considered pharmacologically significant since the beginning of the $20^{\text {th }}$ century, has recently experienced an accelerated growth. These substances demonstrate a characteristically wide spectrum of biological effects, including antimycotic, antibacterial, hypoglycemic, and antineoplastic [1]. Moreover, the high capacity of thiazolidinone core used to accept chemical modifications opens a possibility for development of multitude of novel derivatives potentiating the biological activity of the compound.

The search for new potent antitumor pharmaceuticals possessing high selectivity and low toxicity to normal cells is currently strongly prioritized [2]. Necrostatin-7 (Nec-7) was identified as heterocyclic derivative of 4-thiazolidinone that suppresses TNF$\beta$-induced necroptosis in Jurkat cells (human T-lymphocyte leukemia cell line) deficient in FADD gene [3]. Therefore, the combination of several functional groups in a compound's molecule allows for broader spectrum of its antitumor application.

Novel derivatives of 4-thiazolidinone are synthesized at the Department of Pharmaceutical, Organic and Bioorganic Chemistry of the Danylo Halytsky Lviv National Medical University. The antineoplastic potential of these compounds has been demonstrated [4], particularly by the in vitro studies at the National Cancer Institute (Bethesda, USA). Although the antitumor potential of these compounds is the primary focus of research, it is complemented with various additional effects, e.g. antibacterial, antimycotic, immune-modulating, antidiabetic activity [5-7].

The present study is intended to characterize novel compounds noted as Les-3661 and Les-3713, which are 4-thiazolidinone isomeric derivatives. 
The algorithm of synthesis of these compounds has been established in our previous studies of biological activity in vitro of certain other 4-thiazolidinone derivatives [8]. In order to improve that activity, we have combined parts of Les-3120 molecule containing 3,5-diarylpyrazoline fragment with Les-3372, which is 4-aryliminothiazolidinone derivative with chloro-3-(4-nitrophenyl)-allylidene group. Such combination was done in accordance with hybridpharmacophore approach and was validated by the proven high antitumor potential of pyrazoline-thiazolidinone conjugates as well as by the fact - as it has been demonstrated in our studies - that the structure of arylidene group at $5^{\text {th }}$ position of thiozolidinone core plays an essential role in its antineoplastic activity $[9,10]$.

We have demonstrated that the cytotoxic effect of the new Les-3661 compound is much more potent than that of Les-3120 and Les-3372, which had been characterized earlier. These findings allowed us to assume that Les-3661 possesses high biological activity and might be a potential antineoplastic medicine (Fig. 1).

The aim of the present study is to investigate the effect of novel isomeric 4-thiazolidinone derivatives on viability of tumor cells of various lines in vitro, and to establish potential mechanisms underlying the realization of cytotoxic activity of these compounds.

\section{Materials and Methods}

Cell lines and cell culture. The following cell lines were used in the study: Jurkat (human acute Tcell leukemia), HL-60 (human acute lymphoblastic leukemia), MCF-7 and MDA-MB-231 (human breast adenocarcinoma), HeLa (human cervical carcinoma).

The cells were cultured in the RPMI-1640 and DMEM media (Sigma, USA) supplemented with decomplemented fetal bovine serum (Sigma, USA) and $50 \mu \mathrm{g} / \mathrm{ml}$ of Gentamicin (Sigma, USA) in $\mathrm{CO}_{2}$-incubator at $37{ }^{\circ} \mathrm{C}$ and $5 \% \mathrm{CO}_{2}$ content. The cells were passaged every other day at the density of $0.5 \times 10^{6}$ to $1 \times 10^{6}$ per $1 \mathrm{ml}$ of culture medium.

Analysis of cytotoxic activity. The cells were sub-cultured into 24-well plates (Greiner Bio One, Germany) in the RPMI/DMEM medium with $10 \%$ fetal bovine serum at $0.5 \times 10^{6}$ cells per $\mathrm{ml}$ for suspension cultures or $0.1 \times 10^{6}$ cells per $\mathrm{ml}$ for adherent cultures. The subject compounds were added to cultural medium at various concentrations. After 24-hour incubation, the cells were counted in hemocytometer chamber. The number of dead cells was counted after their staining with $0.1 \%$ solution of trypan blue. This dye colors dead cells, whereas living ones remain colorless [11].

Cytomorphological characterization of ultrastructure of cellular chromatin (staining with DAPI (4',6-diamidino-2-phenylindole) fluorescent dye). Cells were sub-cultered into 6 -well plates $\left(0.1 \times 10^{6}\right.$ cells per well) on glass in DMEM medium with $10 \%$ fetal bovine serum. After 24-hour growth period, the cells were incubated with the investigated compounds for 24 hours, then fixed with $100 \mu 1$ of formalin and $10 \mu \mathrm{l}$ Triton X-100 per sample, and stained with $1 \%$ (in final volume) DAPI (Sigma, USA). The samples were washed with phosphate buffered saline (PBS) and imaged with a digital camera mounted on Zeiss AxioLam A1 microscope (Carl Zeiss, Germany) [12].

Flow cytometry study of cell cycling. The cells subjected to the compound-containing medium were sampled $\left(2 \times 10^{6}\right.$ cells per sample), sedimented by centrifugation for $5 \mathrm{~min}$ at $151 \mathrm{~g}$, and washed twice with PBS. One millilitre of cold PBS $\left(0^{\circ} \mathrm{C}\right)$ was then added to the cells, and the sample was fixed with $4 \mathrm{ml}$ of absolute ethanol at $-20{ }^{\circ} \mathrm{C}$. The cells were stored in this solution at $-20^{\circ} \mathrm{C}$ for no longer than a fortnight [13]. Prior to the flow cytometry procedure, the samples were centrifuged, supernatant liquid was decanted, and the sediments were suspended in $1 \mathrm{ml}$ of PBS. The samples were then incubated with $100 \mu$ l of RNAse $(200 \mu \mathrm{g} / \mathrm{ml}$ concentration) for $30 \mathrm{~min}$ at $37^{\circ} \mathrm{C}$, followed by incubation with $100 \mu \mathrm{l}$ of the propidium iodide $(1 \mathrm{mg} / \mathrm{ml})$ for $5-10 \mathrm{~min}$ at room temperature [14]. The samples were transferred to conical polypropylene test tubes and analyzed by FACSCalibur flow cytometer (Becton-Dickinson, USA).

Western Blot analysis of cellular proteins. The cells of the centrifugation sediment were washed with PBS and then lysed in buffered solution (20 mM Tris- $\mathrm{HCl}, 1 \%$ Triton-X100, $150 \mathrm{mM} \mathrm{NaCl}$, $50 \mathrm{mM} \mathrm{NaF}, 0.1 \%$ SDS, protease inhibitors mix (Complete $^{\mathrm{TM}}$, Roche); $\mathrm{pH}$ 7.6) in proportion of $20 \mu \mathrm{l}$ buffer per $1 \times 10^{6}$ cells. After lysis, the supernatant liquid was separated, mixed with $1 / 3$ part of quadruple Laemmli buffer, and heated in boiling water for $5 \mathrm{~min}$. The samples prepared in this way were afterwards stored at $-20^{\circ} \mathrm{C}$ and analyzed electrophoretically at convenience.

Protein concentration was determined by Peterson's modification of Lowry method [16]. 


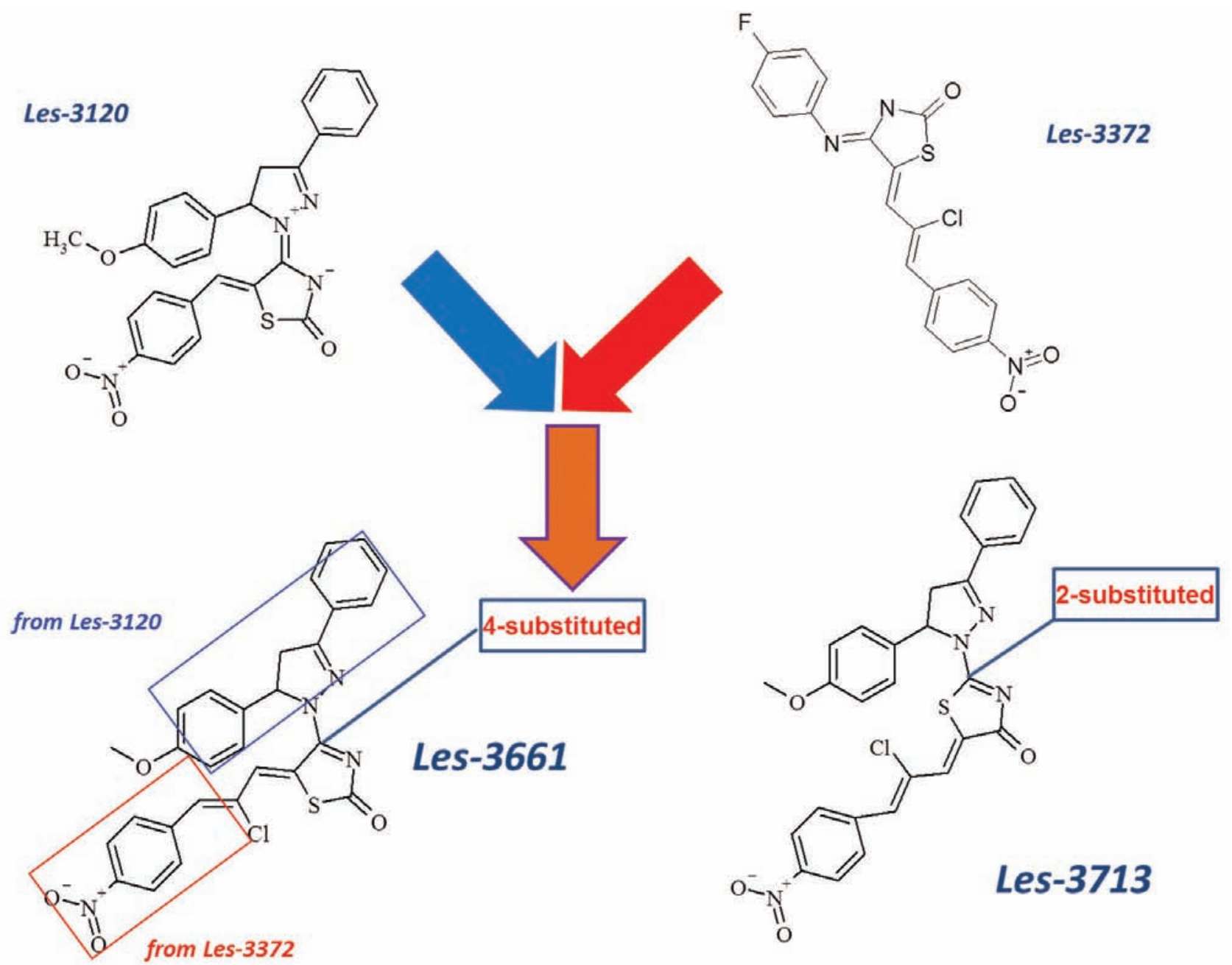

Fig. 1. Basic 4-thiazolidinone structures and their hybrid derivatives

Total protein fraction was separated by vertical polyacrylamide gel electrophoresis (PAGE) in denaturating conditions. The running buffer contained $25 \mathrm{mM}$ Tris, $192 \mathrm{mM}$ glycine, 0.1\% SDS at $\mathrm{pH} 8.3$.

Proteins from PAGE were transferred onto the nitrocellulose membrane in Mini Trans-Blot Cell (BioRad, Sweden) at $90 \mathrm{~V}$ for $90 \mathrm{~min}$ in transfer buffer (0.192 M glycine, 0.1\% SDS, 20\% methanol, $0.025 \mathrm{M}$ Tris, $\mathrm{pH} 8.3$ ). Afterwards, the membrane was blocked at room temperature for $1 \mathrm{~h}$ with $5 \%$ solution of non-fat dry milk in PBS containing $0.05 \%$ Tween 20.

Protein identification on the nitrocellulose membrane was achieved via incubation with specific monoclonal rat or rabbit antibodies raised against pro- and antiapoptotic proteins, followed by incubation with peroxidase-linked antibodies specific for mouse (or rabbit) immunoglobulin (Amersham Pharmacia Biotech, USA). Antibodies were diluted in the blocking solution at $1: 5000$. The incubation was performed with shaking for $1 \mathrm{~h}$ at $4{ }^{\circ} \mathrm{C}$. The membrane was washed three times (5 min each) in the PBS supplemented with $0.05 \%$ Tween 20 .

Specific antibody protein binding was detected via chemiluminescence caused by $1 \mathrm{~min}$ membrane incubation in the detection buffer containing $1.25 \mathrm{mM}$ luminol (5-amino-2,3-dihydro-1,4-phthalazinedione (Sigma)), $2.72 \mathrm{mM}$ p-coumaric acid (4-hydroxycinnamic acid (Sigma)), and $0.01 \%$ hydrogen peroxide in $0.1 \mathrm{M}$ Tris- $\mathrm{HCl}(\mathrm{pH} 8.5)$. Photographic film (Fujifilm, Japan) was exposed on the membrane for 1-10 min and then developed to visualize immunoreactive bands. Protein amount distribution across samples was equalized through $\beta$-actin level in the samples [15].

Statistical analysis. The experiments were conducted in three parallel samples each. Mean value $M$ was obtained through triple repetition of a typi- 
cal assay. Mean deviation $m$ was obtained through standard deviation $\sigma$.

\section{Results and Discussion}

The Les-3661 and Les-3713 compounds were synthesized as described [17]. The primary stage of the present study was aimed at the investigation of the action of Les-3661 and Les-3713 towards tumor cells of various origin and at establishing of their effective acting doses (Fig. 2, A, B). The leukemic tumor cell lines Jurkat (human T-cell leukemia), HL-60 (human promyelocytic leukemia), and also transformed secretory epithelium cell lines MCF-7 and MDA-MB-231 (human breast adenocarcinoma) were used in the experiments. Median lethal concentration $\mathrm{LC}_{50}$ for cells was determined for both 4-thiazolidinone derivatives. $\mathrm{LC}_{50}$ was $3 \mu \mathrm{M}$ for Les3661. LC $_{50}$ for Les-3713 was $42 \mu \mathrm{M}$ for HL-60 and MDA-MB-231 cells, and $47 \mu \mathrm{M}$ for Jurkat and MCF7 cells. The cytotoxity experiments allowed us to establish for the first time the fact that substitutions in the $4^{\text {th }}$ position of the thiazolidinone leads to notable (14-fold) increase in cytotoxicity of Les-3661 compared to $2^{\text {nd }}$ position substituted Les-3713. Les-3661
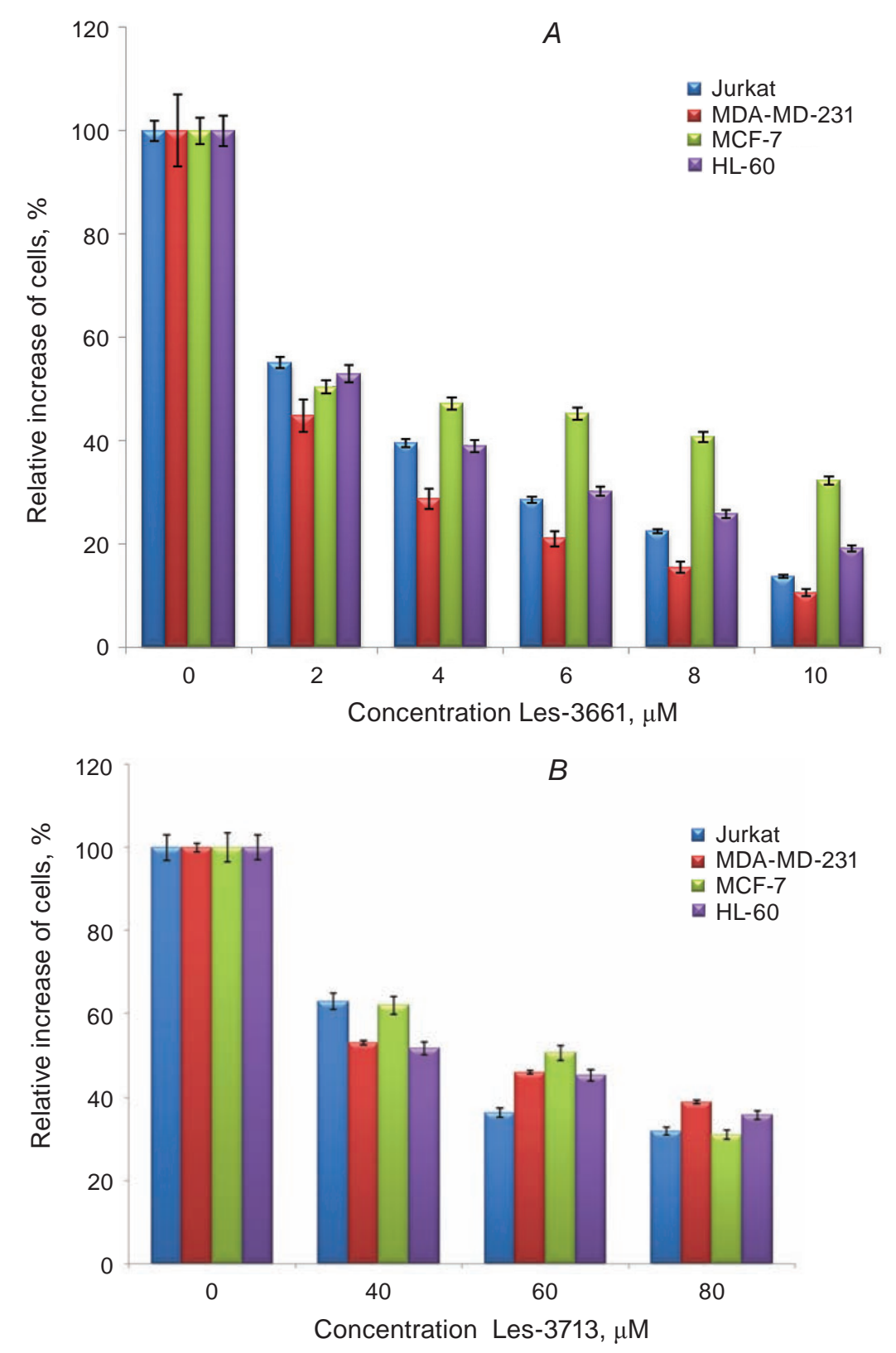

Fig. 2. Cytotoxic effect of Les-3661 (A) and Les-3713 (B) on Jurkat (human T-cell leukemia) and HL-60 (human acute promyelocytic leukemia) cells, MCF-7 and MDA-MB-231 (human breast adenocarcinoma) cells 

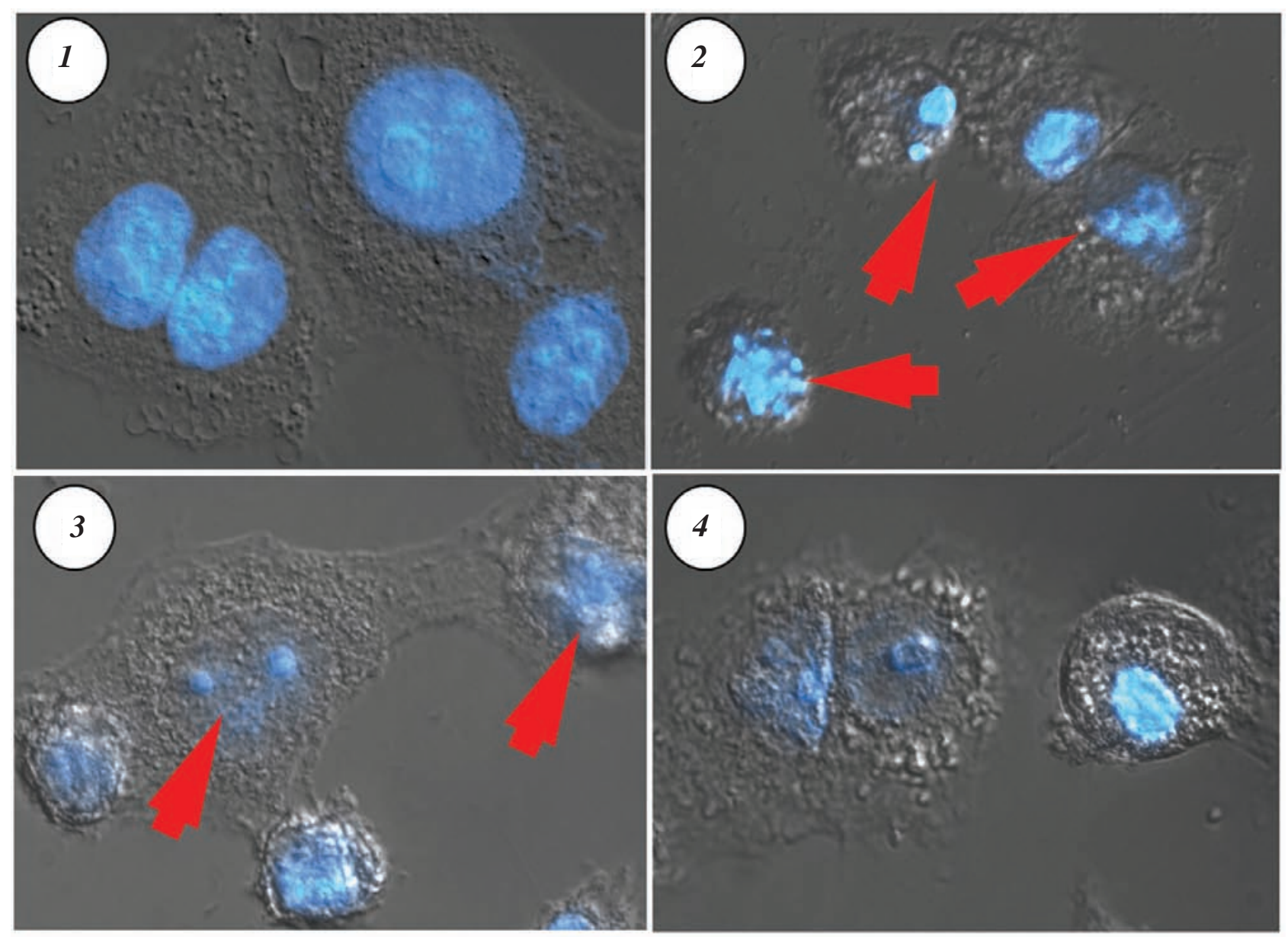

Fig. 3. Cytomorphology of chromatin ultrastructure (DAPI staining) in HeLa cells (24 h): 1 - control; 2 - Les$3661(5 \mu M) ; 3$-Les-3713 (5 $\mu M) ; 4-D x(1 \mu M)$

possessed higher cytotoxicity than its precursor substances. Namely, pyrazoline thiazolidinone Les3661 is 3 times more active than Les-3120 $\left(\mathrm{LC}_{50}\right.$ is $7.5 \mu \mathrm{M})$, and 6 times more active than Les-3372 $\left(\mathrm{LC}_{50}\right.$ is $\left.18 \mu \mathrm{M}\right)$. We also demonstrated that Les-3713 is 5.6 times less cytotoxic than Les 3120 , and 2.3 times less cytotoxic than Les-3372. Therefore, our idea on combination of diverse radicals within single compound for improving its cytotoxic effectiveness has been proven viable in the case of Les-3661 compound.

We investigated the state of chromatin in $\mathrm{HeLa}$ cells (cervical adenocarcinoma) by their staining with DAPI fluorescent dye in order to establish the pathways involved in cell death. The microphotography (Fig. 3) demonstrates that these compounds induce chromatin hyper-condensation that is characteristic of apoptosis, which is the main pathway for transformed cell death under such conditions. Although both compounds were used in concentrations corresponding to $\mathrm{LC}_{50}$ for the cells of these lines, the presented results (Fig. 3) demonstrate that Les-3661 causes more profound chromatin hyper-condensation than Les-3713. We suppose that cells treated with Les-3661 for $24 \mathrm{~h}$ reach terminal stages of apoptosis, while Les-3713 apparently activates apoptotic pathway at later stages.

These results allow one to suggest that Les-3661 and Les-3713 caused transformed cell death via apoptosis, and the cytotoxic effect of Les-3661 is much more profound than such effect of its isomer Les-3713 and of other investigated compounds, such as Les-3120 and Les-3372.

We have also studied Les-3661 effect on tumor cell cycle. Jurkat T-cells were treated with Les-3661 for $24 \mathrm{~h}$, and chromatin was examined using flow cytometry. The data obtained (Fig. 4) demonstrate that Les-3661 affects Jurkat cell cycle and increases the number of cells in $\mathrm{G}_{0} / \mathrm{G}_{1}$ phase $(19.71 \%$ more than in control), while doxorubicin increases the number of 

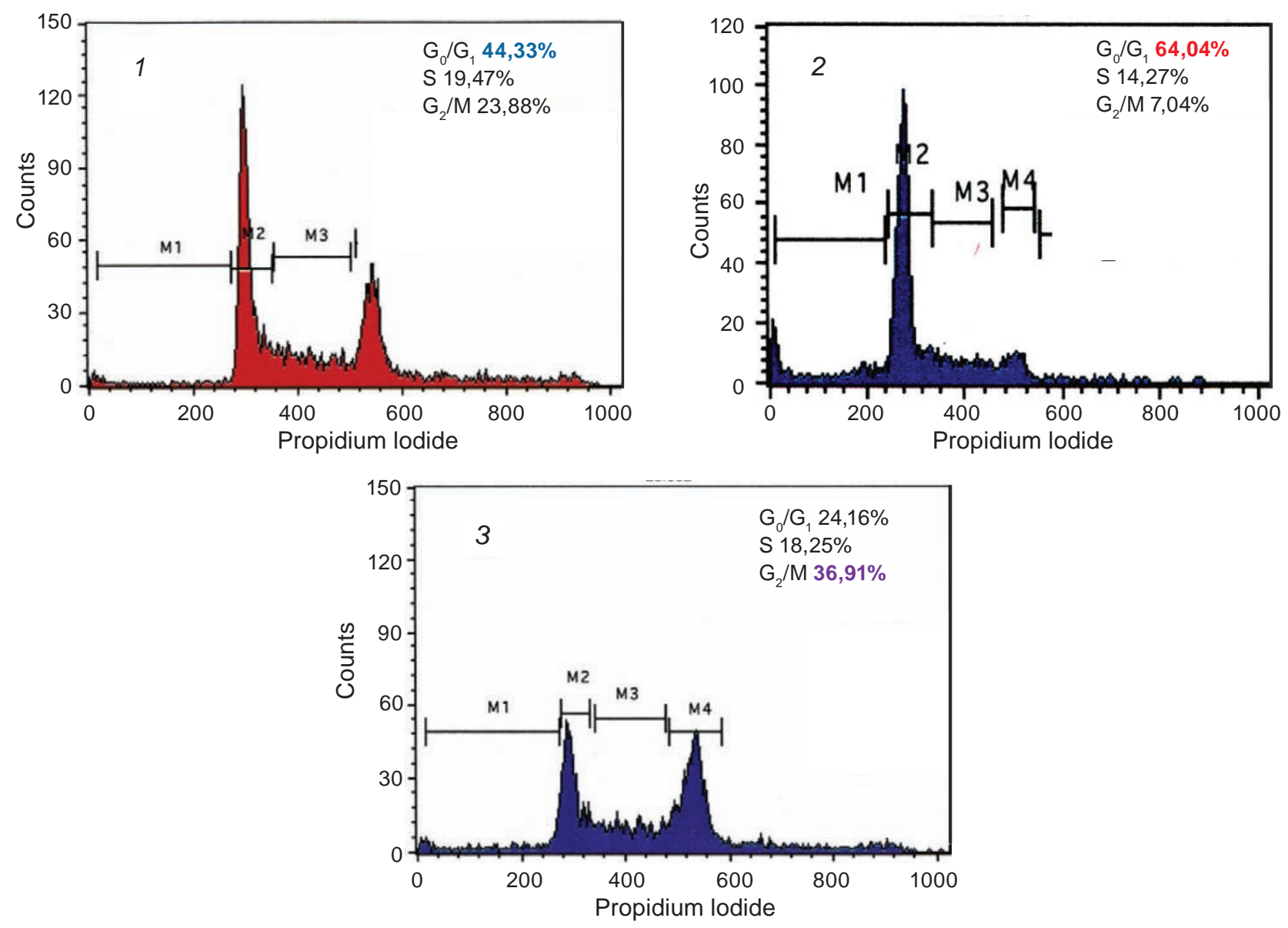

Fig. 4. Flow cytometry analysis of cell cycle in Jurkat cells after 24 h incubation with Les-3661: 1 - control; 2 -Les-3661 (3 $\mu \mathrm{M}) ; 3$-doxorubicin $(0.5 \mu M)$

$\mathrm{G}_{2} / \mathrm{M}$ phase cells. This makes evident the differences in underlying mechanisms of action of doxorubicin and 4-thiazolidinone derivative.

Western blot analysis of proteins involved in initiation and execution of apoptosis was used to explore molecular mechanisms underlying the activity of the investigated heterocyclic compounds. The lysates were obtained from Jurkat line T-leukemia cells treated for $1,3,6,12$, and $24 \mathrm{~h}$ with Les-3661 $(3 \mu \mathrm{M})$ and Les-3713 $(42 \mu \mathrm{M})$, and with doxorubicin $(0.5 \mu \mathrm{M}$, used as positive control). The experiments on initiation of apoptosis under the effect of 4-thiazolidinone derivatives revealed that $12 \mathrm{~h}$ treatment of cells with Les-3661 compound is enough to decrease the intracellular level of the procaspase- 8 (Fig. 5). That can be associated with activation of this proteolytic enzyme and the induction of receptor-mediated apoptosis. The proteolysis product of the procaspase-9 which activates mitochondrial apo- ptosis pathway appears after $12 \mathrm{hr}$ treatment. Conversely, the concentration of the monomer form of Bid proapoptotic protein was decreased, apparently due to its dimerization and formation of tBid which participates in the mitochondrial membrane permeability. This leads to a release of cytochrome $\mathrm{c}$ and subsequent formation of the apoptosomes through mitochondria-mediated apoptosis pathway. The intracellular level of other proapoptotic proteins, such as procaspase-2 (responsible for mitotic catastrophe and nuclear apoptosis) and procaspase-10 (responsible for receptor-dependent apoptosis), decreases later, at $24 \mathrm{~h}$ of treatment with the compound under study.

Our data allows us to conclude that Les-3661 induces mixed-type apoptosis that involves pathways of receptor-mediated as well as mitochondrial apoptosis. In analogy to Les-3661 effect, cell treatment with Les-3713 activates the initiation caspase-9 and 


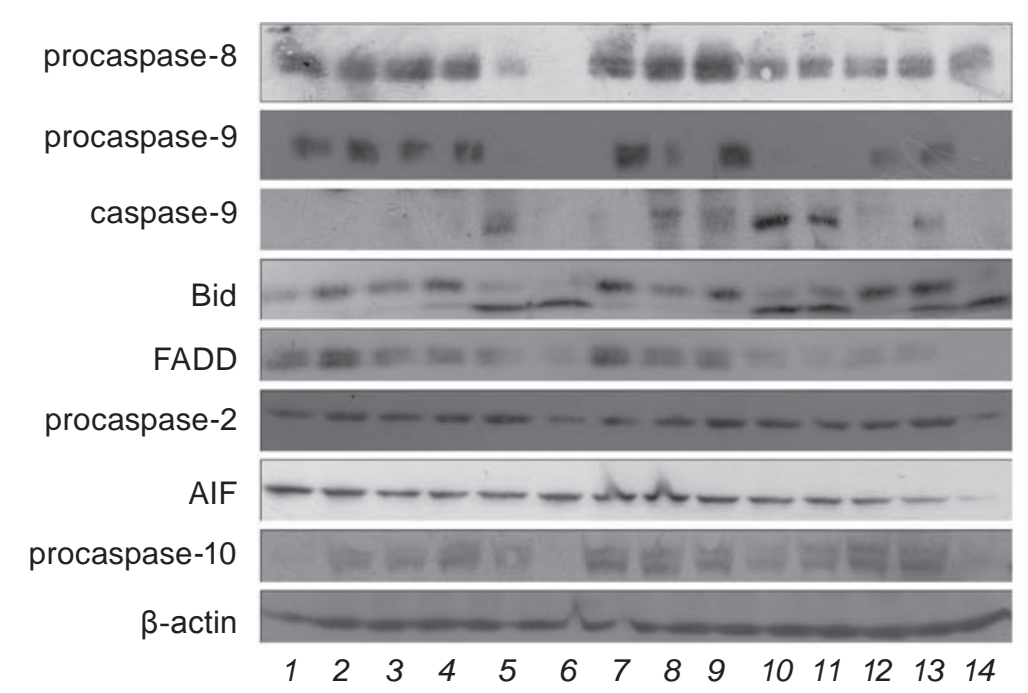

Fig. 5. Western blot analysis of apoptosis initiating proteins in Jurkat (human T-cell leukemia) cells under effect of 4-thiazolidones: 1 - control; 2 -Les-3661, $3 \mu \mathrm{M}, 1 \mathrm{~h}$; 3 -Les-3661, $3 \mu \mathrm{M}, 3 \mathrm{~h}$; 4 -Les-3661, $3 \mu \mathrm{M}$, 6 h; 5 -Les-3661, $3 \mu M, 12$ h; 6 -Les-3661, $3 \mu M, 24 h ; 7$-Les-3713, $42 \mu M, 1$ h; 8-Les-3713, 42 $\mu M, 3$ h; 9-Les-3713, $42 \mu M, 6$ h; 10 -Les-3713, $42 \mu M, 12$ h; 11 -Les-3713, $42 \mu M, 24$ h; 12 -Dox, $0.5 \mu M, 6$ h; 13 Dox, $0.5 \mu M, 12 h ; 14-D o x, 0.5 \mu M, 24 h$

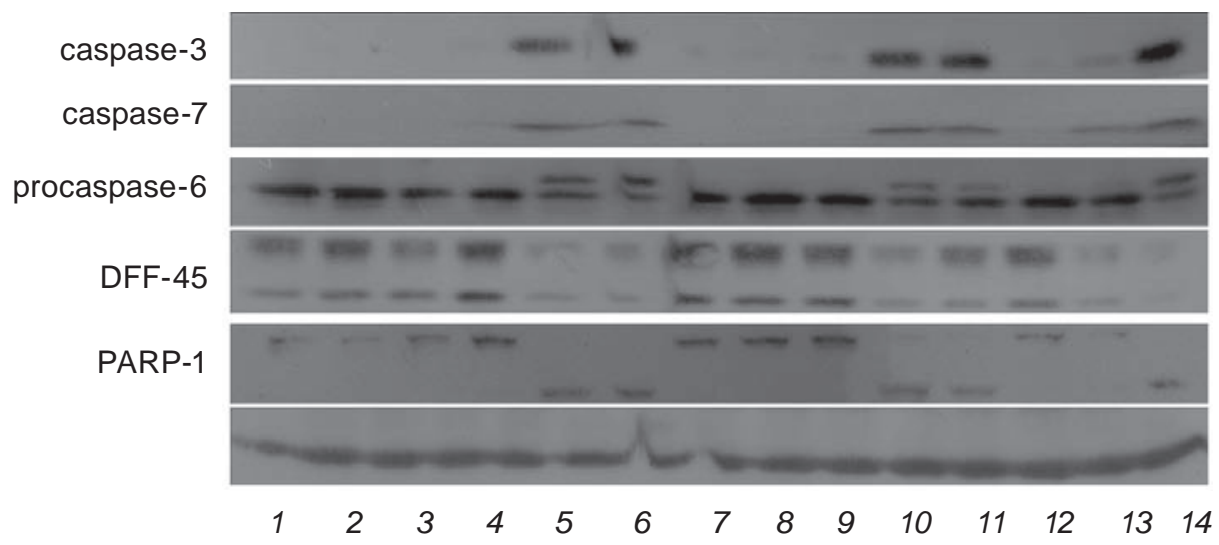

Fig. 6. Western blot analysis of apoptosis effector proteins in Jurkat (human T-cell leukemia) cells under effect of 4-thiazolidones: 1 -control; 2 -Les-3661, $3 \mu \mathrm{M}, 1$ h; 3 -Les-3661, $3 \mu \mathrm{M}, 3$ h; 4 -Les-3661, $3 \mu \mathrm{M}$, 6 h; 5 -Les-3661, $3 \mu \mathrm{M}, 12$ h; 6 -Les-3661, $3 \mu \mathrm{M}, 24$ h; 7 -Les-3713, $42 \mu \mathrm{M}, 1$ h; 8-Les-3713, $42 \mu \mathrm{M}, 3$ h; 9-Les-3713, $42 \mu M, 6$; 10 -Les-3713, $42 \mu M, 12$ h; 11 -Les-3713, $42 \mu M, 24$; 12 -Dox, $0.5 \mu M, 6 h$; 13 Dox, $0.5 \mu M, 12$ h; $14-D o x, 0.5 \mu M, 24 h$

decreases content of Bid protein in the targeted cells. Therefore, only the mitochondrial apoptotic pathway is activated in cells under effect of Les-3713.

The effector phase proapoptotic proteins, such as caspase-3, caspase- 7 and caspase- 6 are activated at $12^{\text {th }} \mathrm{h}$ of cell treatment with Les-3661 and Les3713 (Fig. 6). This effect is accompanied by degradation of the reparation enzyme PARP-1 (poly-[ADPribose]-polymerase) and activation of the regulatory protein DFF-45 (DNA-fragmentation factor).
On Fig. 7 the pattern of possible mechanisms of action for various 4-thiazolidinone derivatives is presented. As shown, Les-3661 induces mixed-type apoptosis via caspase-8 which initiates receptor-mediated apoptosis, and via caspase-9 participating in mitochondrial cell death pathway. This might lead to elimination of malignant cells with mutations in genes of programmed cell death regulation. Apparently, extensive antitumor potential of Les-3661 is determined by its ability to affect diverse apoptotic 


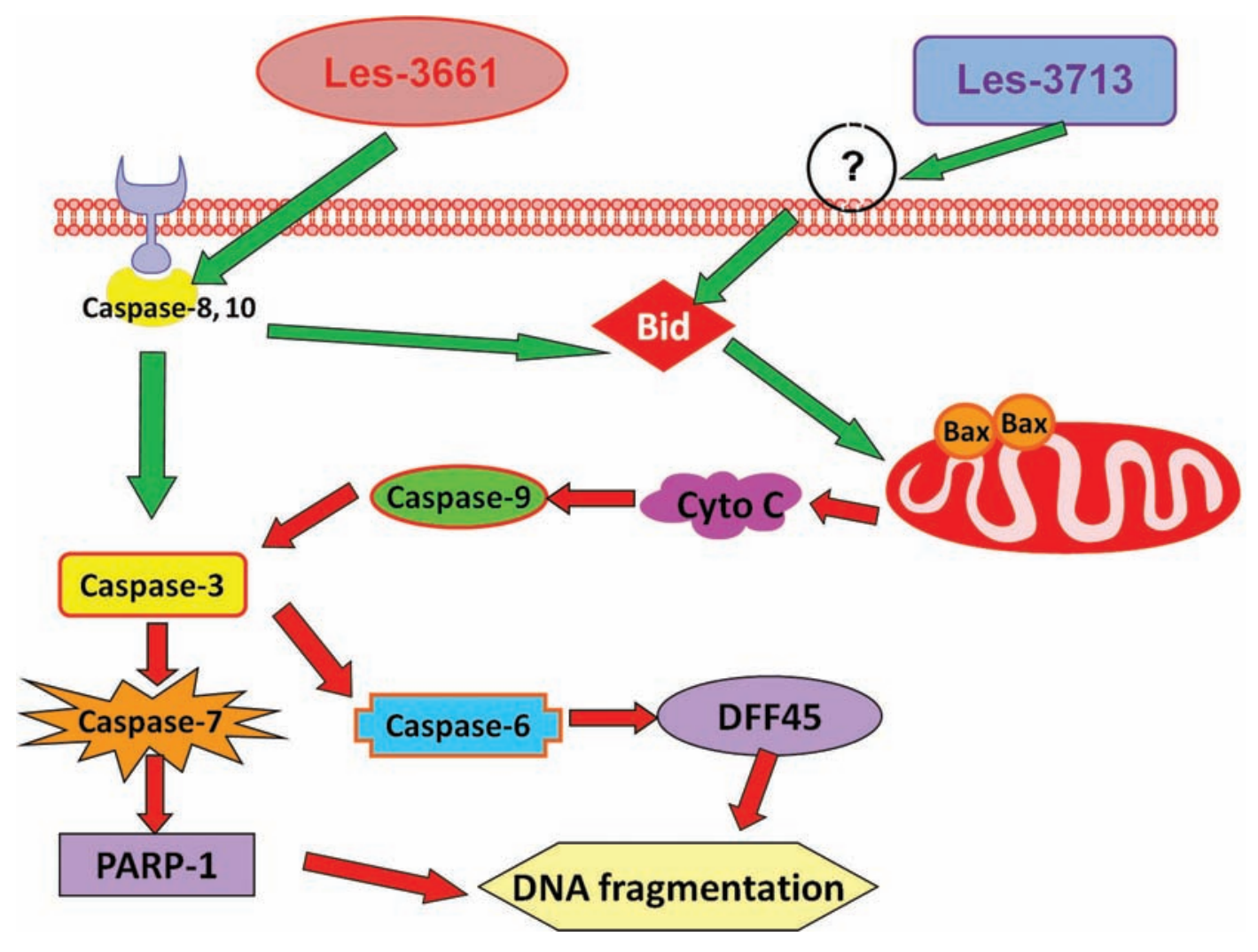

Fig. 7. Molecular mechanisms underlying the action of heterocyclic Les-3661 and Les-3713 compounds

signaling pathways. Unlike Les-3661, Les-3713 is only capable of inducing mitochondria-mediated apoptosis, which probably explains its less pronounced cytotoxic efficiency.

Les-3661 and Les-3713 induce apoptosis initiation and activate effector proteins earlier than doxorubicin does initiating apoptosis at $24^{\text {th }} \mathrm{h}$ of cell treatment (Fig. 5 and 6). This fact provides grounds for further preclinical in vivo study of certain 4-thiazolidinones, mainly Les-3661 which is much more active than Les-3713 isomer.
Thus, a combination of pyrazoline, 2-chloro3-(4-nitrophenyl)-allylidene and thiazolidinone moieties in one molecular structure substantially potentiates the antineoplastic efficiency of the precursor compounds possessing such groups. Moreover, such a 'hybrid' molecule is more powerful and faster inducer of apoptosis in tumor cells. 3,5-Diarylpyrazoline group which is present in $4^{\text {th }}$ position of Les-3661's thiazolidinone fragment ensures its much enhanced antineoplastic efficiency in comparison to Les-3713 isomer which has this group in $2^{\text {nd }}$ position of the thiazolidinone fragment. 


\section{ДОСЛІДЖЕННЯ \\ АНТИНЕОПЛАСТИЧНОї ДІї НОВИХ ІЗОМЕРНИХ ПОХІДНИХ 4-ТІАЗОЛІДИНОНУ}

\author{
B. В. Чумак ${ }^{1,2}$, М. Р. Філь ${ }^{2}$, Р. Р. Панчук ${ }^{2}$, \\ Б. С. Зіменковський, Д. Я. Гаврилюк \\ Р. Б. Лесик ${ }^{3}$, Р. С. Стойка ${ }^{1,2}$
}

${ }^{1}$ Львівський національний університет імені Івана Франка, Україна;

${ }^{2}$ Інститут біології клітини НАН України, Львів;

3Львівський національний медичний університет імені Данила Галицького, Україна; e-mail:virachumak@gmail.com

Піразол- і арилзаміщені похідні 4-тіазолідинону належать до перспективних сполук із протипухлинною активністю. Наші попередні дослідження кількох представників групи 4-тіазолідинонів показали їх виражену токсичну дію in vitro щодо ліній злоякісних клітин. 3 метою потенціювання протипухлинної активності новітніх 4-тіазолідинонів ми здійснили дизайн і синтезували піразолінотіазолідинони, в молекулах яких поєднані ймовірні фармакофорні центри попередньо тестованих сполук цього типу. Показано, що синтезовані «гібридні» похідні 4-тіазолідинону $\epsilon$ токсичними для злоякісних клітин різного походження in vitro. Механізми антинеопластичної активності цих сполук та їхня здатність індукувати апоптоз виявилися залежними від положення замісника у тіазолідиноновому циклі. Зокрема, сполука Les-3661, що містить піразоліновий фрагмент у 4-му положенні тіазолідинонового циклу, виявляє в 14 разів вищу токсичну дію щодо злоякісних клітин $\left(\mathrm{LC}_{50}=3\right.$ мкM), ніж $\dddot{11}$ ізомер Les-3713 із заміщенням у 2-му положенні ( $\mathrm{LC}_{50}=42$ мкM). Що стосується механізмів цитотоксичної дії, то сполука Les-3661 індукує апоптоз змішаного типу, залежний від каспази-8 і каспази-9, тоді як сполука Les-3713 індукує апопто3, опосередкований лише каспазою-8.

К л ючов і слов а: 4-тіазолідинони, механізми протипухлинної дії, лінії пухлинних клітин.

\section{ИССЛЕДОВАНИЕ \\ АНТИНЕОПЛАСТИЧЕСКОГО ДЕЙСТВИЯ НОВЫХ ИЗОМЕРНЫХ ПРОИЗВОДНЫХ 4-ТИАЗОЛИДИНОНА}

\author{
В. В. Чумак $\kappa^{1,2}$, М. Р. Филь ${ }^{2}$ Р. Р. Панчук², \\ Б. С. Зименковский, Д. Я. Гаврилюк \\ Р. Б. Лесык ${ }^{3}$, Р. С. Стойка,
}

\author{
1Львовский национальный университет \\ имени Ивана Франко, Украина; \\ ${ }^{2}$ Институт биологии клетки НАН Украини, Львов; \\ 3 Львовский национальный медицинский \\ университет имени Данила Галицкого, Украина; \\ e-mail: virachumak@gmail.com
}

Пиразол- и арилзамещенные производные 4-тиазолидинона являются перспективной группой соединений с противоопухолевой активностью. Наши предыдущие исследования нескольких представителей группы 4-тиазолидинонов показали их выраженное токсическое действие in vitro на линии злокачественных клеток. С целью потенцирования противоопухолевой активности новых 4-тиазолидинонов нами осуществлен дизайн и проведен синтез пиразолино-тиазолидинонов, в которых объединены в одной молекуле фармакофорные центры ранее тестированных соединений. Установлено, что синтезированные «гибридные» производные 4-тиазолидинона вызывают гибель in vitro злокачественных клеток разного происхождения. Механизмы антинеопластической активности этих веществ, а также еффективность индукции ими апоптоза зависят от положения заместителя в тиазолидиноновом цикле. Соединение Les-3661, содержащее пиразолиновый фрагмент в 4-ом положении тиазолидинонового цикла, обладает в 14 раз более высокой цитотоксической активностью по отношению к злокачественным клеткам ( $\mathrm{LC}_{50}=3$ мкM), чем его изомep Les-3713 с замещением во 2-ом положении $\left(\mathrm{LC}_{50}=42\right.$ мкM). Установлено, что соединение Les-3661 индуцирует апоптоз смешанного типа, зависящий от каспазы-8 и каспазы-9, тогда как соединение Les-3713 индуцирует апопто3, опосредуемый только каспазой-8.

К л юче вы е с ло в а: 4-тиазолидиноны, механизмы противоопухолевого действия, линии опухолевых клеток. 


\section{References}

1. Lesyk R. B., Zimenkovsky B. S. 4-Thiazolidones: Centenarian history, current status and perspectives for modern and organic and medicial chemistry. Curr. Org. Chem. 2004;8(16):15471577.

2. Zimenkovsky B. S., Lesyk R. B. 4-thiazolidones. Chemie, physiological action, perspectives. Vinnytsya: Nova Knyga, 2004. P. 106.

3. Zheng W., Degterev A., Hsu E., Yuan J., Yuan C. Structure-activity relationship study of a novel necroptosis inhibitor, necrostatin-7. Bioorg. Med. Chem. Lett. 2008;(18):4932-4935.

4. Lesyk R. B.,ZimenkovskyB. S., Kaminskyy D. V., Kryshchyshyn A. P., Havrylyuk D. Ya., Atamanyuk D. V., Subtel'na I. Yu., Khyluk D. V. Thiazolidinone motif in anticancer drug discovery. Experience of DH LNMU medicinal chemistry scientific group. Biopolym. Cell. 2011;27(2):107-117.

5. Havrylyuk D., Zimenkovsky B., Vasylenko O., Lesyk R. Synthesis, anticancer and antiviral activity of new 2-pyrazoline substituted 4-thiazolidinones. J. Heterocycl. Chem. 2013;(50):55-62.

6. Havrylyuk D., Zimenkovsky B., Vasylenko O., Day C. W., Smee D. F., Grellier P., Lesyk R. Synthesis and biological activity evaluation of 5-pyrazoline substituted 4-thiazolidinones. Eur. J. Med. Chem. 2013;(66):228-237.

7. Zimenkovsky B. S., Lesyk R. B. 4-thiazolidones and their та related heterocyclic systems. New research directions of Pharmaceutical, Organic and Bioorganic Chemistry of Danylo Halytsky Lviv National Medical Univesity. Clin. Pharm. Pharmacother. Med. Standard. 2010;(3-4):14-31.

8. Panchuk R. R., Chumak V. V., Fil' M. R., Havrylyuk D. Ya., Zimenkovsky B. S., Lesyk R. B., Stoika R. S. Study of molecular mechanisms of proapoptotic action of novel heterocyclic 4-thiazolidone derivatives. Biopolym. Cell. 2012;28(2):121-128.
9. Havrylyuk D., Zimenkovsky B., Vasylenko O., Zaprutko L., Gzella A., Lesyk R. Synthesis of novel thiazolone-based compounds containing pyrazoline moiety and evaluation of their anticancer activity. Eur. J. Med. Chem. 2009;(44):1396-1404.

10. Havrylyuk D., Zimenkovsky B., Vasylenko O., Gzella A., Lesyk R. Synthesis of new 4-thiazolidinone-, pyrazoline-, and isatin-based conjugates with promising antitumor activity. J. Med. Chem. 2012;(55):8630-8641.

11. Freshney R. Culture of animal cells. Moskow: Myr, 1989. P. 257-276. (In Russian).

12. Hsiao W.-T., Tsai M.-D., Jow G.-M., Tien L.-T., Lee Y.-J. Involvement of Smac, p53, and caspase pathways in induction of apoptosis by gossypol in human retinoblastoma cells. Mol. Vis. 2012;(18):2033-2042.

13. Jayadev S. Flow Cytometric Analysis of Cell Cycle. Exp. Cell Res. 1994;(207):142-151.

14. Hsueh R., Roach T. Quantification of Apoptosis and the Cell Cycle Distribution of Primary B Cells Using Propidium Iodide AfCS Procedure. Protocol 02/15/02.

15. Janus P., Pakuia-Cis M., Kalinowska-Herok M., Kashchak N., Szoitysek K., Pigiowski W., Widlak W., Kimmel M., Widlak P. NF-kB signaling pathway is inhibited by heat shock independently of active transcription factor HSF1 and increased levels of inducible heat shock proteins. Genes Cells. 2011;(16):1168-1175.

16. Darbre A. Practical protein chemistry. Moskow: Myr, 1989. P. 295-296. (In Russian).

17. Havrylyuk D., Zimenkovsky B., Vasylenko O., Zaprutko L., Gzella A., Lesyk R. Synthesis of novel thiazolone-based compounds containing pyrazoline moiety and evaluation of their anticancer activity. Eur. J. Med. Chem. 2009;44(4):1396-1404.

Received 23.01.2014 